\title{
A tenant's lot: on paying the rent or facing the prospect of eviction - a response to Bazerman
}

\section{O quinhão do inquilino: pagar o aluguel ou enfrentar a perspectiva de despejo - uma resposta ao Bazerman}

Kanavillil Rajagopalan

State University at Campinas (Unicamp)

\begin{abstract}
Bazerman's point (cf. Bazerman, this issue of RBLA) that the whole notion of plagiarism is beset with a fundamental, conceptual paradox is argued to be absolutely right as far as it goes but is shown to be only one of a plethora of inter-related paradoxes that plague the entire conceptual field. On the one hand, this makes plagiarism a concept (if at all it is one!) so very difficult to grapple with and particular cases of alleged plagiarism next to impossible to pin down with any amount of clarity or hundred per cent certainty. But on the other hand, it is perfectly reasonable to continue viewing the issue of plagiarism as an ethical one though not necessarily a moral imperative.
\end{abstract}

KEYWORDS: Bazerman, plagiarism, originality, paradox, ethics.

RESUMO: O ponto de vista de Bazerman (cf. Bazerman, nesta edição da RBLA) de que a noção de plágio é cercada de um paradoxo conceitual, fundamental está absolutamente correto até certa medida, mas isso é apenas um de uma multiplicidade de paradoxos inter-relacionados que infestam todo o campo conceitual. Por um lado, isso faz do plágio um conceito (se é que poderíamos considerá-lo assim!) muito difícil de lidar, com casos particulares de suposto plágio quase impossíveis de serem identificados com clareza ou absoluta certeza. Mas, por outro lado, é perfeitamente razoável continuar a ver a questão do plágio como uma questão ética, embora não necessariamente um imperativo moral.

PALAVRAS-CHAVE: Bazerman, plágio, originalidade; paradoxo; ética.

*rajagopalan@uol.com.br 
In his thought-provoking piece, "Paying the Rent: Languaging Particularity and Novelty", Charles Bazerman wraps up his thoughts by pointing to a curious paradox that foils our best efforts to make sense of creativity and originality (scientific, artistic or whatever) against the backdrop of what is already out there as part of the archive comprising the collective achievements of the society as a whole and what therefore forms the common pool of resources that every one of its members is free to draw from. Rather than there existing an inverse relation of respective salience that the presumably figure-ground equation between the two would make us predict, it turns out to be the case that the greater the part one is in a position to credit to the already familiar stock, the more original and innovative the new element would appear to be. Alternatively, the newness of the new element, or the figure, seems to increase in tandem with our familiarity with the ground. Or put it even more starkly, the newness of the new is dependent in a fundamental sense upon the extent to which it can presuppose the things that make up its context or immediate co-text. Or, as Bazerman puts it: "Only by drawing deeply from the collective resources can we add most fully to them and pay our share of the rent." Bazerman concludes that this paradox directly feeds into and helps exacerbate what he calls the "plagiarism paranoia" afflicting especially the academic community, putting insurmountable "barriers" between, say, teachers and students.

Bazerman has, it seems to me, identified what in the end makes the whole issue of plagiarism so intriguing and, in the ultimate analysis, hopelessly intractable. But, while fully endorsing his brilliant analysis, I would also like to note that the entire area triangulated by bearings provided by the threesome of concepts 'plagiarism, imitation and originality' that Bazerman surveys is a veritable mine-field of aporias.

Bazerman is right on track in linking the idea of plagiarism to that of originality. The two are like a pair of Siamese twins: the very existence of the one is viscerally tied to that of the other. Anyone claiming to have identified a case of plagiarism is, in so doing, also thereby claiming to know that there is an original corresponding to it (be it a work of art, a literary piece, a scientific article or a simple idea) whose originality has been established beyond any reasonable doubt. But then the million-dollar question is: how does one tell an original when one sees one?

A typically Nietzschean answer would run along the following lines: An original is quite simply that which can potentially at least be imitated or 
falsified (i.e., forged, counterfeited, dissembled, etc.). Falsifiability in this sense $^{1}$ or forgeablity is, it would seem, just what makes an original what it is. Or, if you like, falsifiability is constitutive of the originality or the authenticity of the original. As mind-boggling as this might indeed appear at first blush, falsification is not an unforeseen and untoward accident that may befall an original but the ever-present possibility of falling prey to it is the price it has to be ready to pay for ever for being entitled to wearing the badge of originality and authenticity. Or, to play on the metaphor Bazerman resorts to in contemplating the issue at hand, it is only the owner of the real estate who can rent or lease it to someone else which, come to think of it, in effect makes rentability or leasability constitutive of the very concept of ownership.

But here we seem to be heading for a mental stalemate. If falsifiability is part and parcel of the very concept of the original, of the originality of the original, how can we sensibly make a case for the prohibition of the falsification of the original, of falsely claiming as one's own what is supposed by common consent to originally and rightfully belong to someone else? Wouldn't that amount to denying the original that which is of its very essence? Alternatively, how can we expect the original to continue being original once it has been rendered proof against all possibilities of falsification or cheap imitation?

The mental stalemate that we are up against here is analogous to the one that famously confronted the French anthropologist Claude Lévi-Strauss as he tried to figure out the exact nature of incest and prohibition thereof in different societies across the world. His own gut feeling after years of fieldwork in different parts of the world that he could not even think of a human society where incest would be tolerated as perfectly normal and hence prohibition of incest deserved to be treated as a universal ran up against the equally powerful argument that it could not be considered a universal for the simple reason that the very idea of a prohibition entailed the ever-present possibility of the act taking place were it not for the prohibition.

Caught on the two horns of this excruciating dilemma, Lévi-Strauss opts to leave in suspense the whole issue and press ahead with other, more tractable problems of anthropology. As Jacques Derrida points out in his essay "Structure, Sign, and Play in the Discourse of the Human Sciences"

${ }^{1}$ Note that I am using the word "falsifiability" in a sense markedly different from the one made popular by Karl Popper. 
(DERRIDA, 1978 [1967]), Lev-Strauss is content to treat the problem posed by incest as a veritable "scandal" and leave matters at that for good.

The aporia that Derrida identifies in Lévi-Strauss's thinking may lie at the heart of the paradox that Bazerman claims to have spotted as he examines the problematic of plagiarism. In saying so, I am, among other things, drawing attention to the fact that the introduction of the internet has, as Bazerman rightly points out at the outset, only brought into relief (thanks to ease of access to a seemingly endless archive of material stacked away in libraries across the world) what has always already been an endemic issue insofar as plagiarism is concerned: how does one pin down a case of plagiarism with absolute certainty? Or, how to resolve "the tension between intellectual property and the cultural commons"?

This eternal dilemma of identifying for sure instances of crass and blatant plagiarism has to do with the more fundamental question of where to draw the line between what is truly innovative or in Bazerman's words, "bring[ing] in unique material and think[ing] fresh thoughts in relation to them" and of drawing on the common pool of publicly available and freely accessible archives of information. Of course, there is the additional need to recognize the specificities of different domains and what are consensually taken to be the norms of conduct established in each domain.

A judge, while arriving at decisions and dealing out justice, is required to stick strictly to the business of interpreting the law of the land and not be seen as transgressing that limit by making new laws. Or, as the old adage says, Jus dicere, et non jus dare. But how does one know for sure one is only interpreting the law and not saddling the letter of the law with new meanings? The problem becomes all the more urgent if we grant that part of interpreting the law involves applying it to hitherto unforeseen cases and hence taking it to uncharted territories. To be sure, it is also the case that all too frequently this involves prizing the law out of the specific set of circumstances in which it was originally enacted and making it apply to a fresh set of circumstances, separated from the original circumstances in space and time.

Does adapting something (a law, a principle-you name it) to a situation for which it was not originally intended still count as merely applying it or will it instead qualify as extending it, and in the process, altering it in non-trivial ways? As Bazerman points out, "Depending on the question, a student may be expected to draw fresh implications, applications, or conclusions, but wandering too far into the student's own thoughts risks falling into error or off the topic". 
Drawing on the work of Grice, one may venture that the line must be drawn somewhere between implication and implicature, so that all logically demonstrable implications will remain on one side and within the allocated ken of the judge, while all implicatures would be seen as off-limits for the judge. After all, isn't defeasibility the key defining feature of implicature? But such an ad hoc solution will hardly bring matters to an end, for, as already pointed out, the judge has to bring to bear on the case new, hithertouncontemplated factors that were simply undreamt of by the lawmakers when they enacted those laws, so the analogy with a logical operation, say a syllogism, may be seen as breaking down precisely at this point (This, by the way, is what makes resolving ethical issues a tight-rope walking exercise of enormous complexity).

One thing that the considerations made in the foregoing paragraphs highlight is that the problem of plagiarism also brings to the fore the intricate connections between creativity and convention. Once again, Bazerman is right in warning us that care should be taken not to pass the steamroller of uniformization over domains that have distinct internal norms. Unlike the Law where convention is prized over creativity (and jurisprudence weighs in to make sure that judges do not make any wayward decisions by taking the law into their own hands and passing judgments in accordance with their own sweet will and pleasure), the domain of academic writing is, in principle at least, supposed to reward creativity and value it over convention (despised and downgraded as mere cud-chewing!). The difference between original research and writing lecture notes or introductory textbooks is believed to consist in this: in the former, creativity is foregrounded; in the latter, it is mostly conventional wisdom that is supposed to be ladled out.

But even here there are constraints and some important caveats. Depending on a whole slew of factors, just how "original" and "daringly innovative" the writer is allowed to be is a matter of great significance. In general, a student writing her Master's thesis or a Ph. D. dissertation is required to display a solid "grounding" in the field of study, along with whatever it is that she can claim as new and fruit of her own "original" thinking. Also, what the committee invariably looks for is a fine balance between the one and the other. The committee in general expects the candidate to establish her credentials as a future member of their select club by declaring and reiterating the founding principles of the discipline. But they also expect of the candidate some "original" contribution to the already existing body of knowledge. 
This brings us to the tricky question of just what constitutes "newness" or what Bazerman calls the "ring of novelty". Salman Rushdie once famously defined it as "mélange, hotch-potch, a bit of this and a bit of that." (RUSHDIE, 1990). That is to say, the ingredients might be all familiar, but the way they are mixed in the crucible is, along with the combination and the proportion of each ingredient, is unfamiliar. The recipe must be new, but the taste, the overall flavor, must be familiar enough so as not to be too ornate for the palate. Note that here there is no logical way to track down an "original substance" for the simple reason that they are as many origins as there are ingredients in the mixture (We are making the further rather unwarranted assumption that each of these ingredients has an originary "purity" so as not to be new in relation to anything else-the absolute, originary original!, but never mind that!)

The fundamental paradox that Bazerman detects in respect of newness and the set of conventions that forms its backdrop is to be found at its best in what is presented to us in the form of a thesis or dissertation, the crowning moment of a student's entire career as an aspirant to a place of honor in academia. If, following an accepted convention, the author of the thesis kicks off her discussion with an opening statement to the effect that "in this thesis, I propose to study the phenomenon of (...) (...) strictly within the framework of the theory of $(\ldots)(\ldots)$ as proposed by $(\ldots)(\ldots)$ ", we can be sure that the thesis as a whole fits, strictly speaking, within one or the other of the following two categories: either (a) the thesis churns out a whole lot of pure gibberish without contributing an iota of new knowledge to what is already there in the existing literature on the topic, or (b) if it does succeed in saying something new, it does so only by not living up to the initial promise, i.e. by not staying within the confines of the theory as solemnly promised and either extending it in ways not originally envisioned or modifying it in ways that partially or seriously compromise the claims made by the original proponents of the theory. In other words, in its most rigorous sense, no thesis can live up to the twin promises its author makes of staying strictly within the limits of the theory she has chosen to work with and saying something new, something that can really count as genuinely new, i.e., not already contemplated by the theory, albeit as a mere potentiality.

In other words, an academic thesis is, in the strictest sense of the word, an elaborate and intricate exercise in make-believe. One either pretends one is well grounded in a venerable theoretical tradition and faithful to its doctrinal 
principles and says something original and new. Or one obstinately and resolutely remains faithful to all the dictates of the theory one has chosen to work with and pretends one is saying in addition things of one's own creative genius that are worth the effort. It is always and invariably either one or the other. Never both.

The moral of the story is this. There is no way of tackling the issue of plagiarism on a conceptual plane. It is not an idea that lends itself to a rigorous analysis in terms of cut-and-dried dichotomous oppositions. It is, when all is said and done, not a concept properly speaking, since we are here dealing with an idea that is fundamentally paradox-ridden. But just because it is so very difficult or even impossible to pin it down, it doesn't mean we must throw it overboard. We all have a rough-and-ready idea of what makes a given case one of plagiarism, though our intuitive feelings in this respect (along the lines of Bourdieu's "feel for the game") may not stand the test of rigorous conceptual analysis or steel-hard criteria established by the Law. Just as in all other ethical issues - and plagiarism, let us remind ourselves once gain, is first and foremost an ethical issue - we are walking a very thin tight-rope here and, what is worse, with no safety net below in case a false step is taken. For the truth of the matter is that, in very many cases, there is a radical undecidability in coming to any definitive decision. ${ }^{2}$

In sum, what I am striving to drive home is that the paradox that Bazerman so astutely pinpoints is only one among a whole gamut of interrelated ones. They are there all over the place. But the show must go on and as the lyric says:

Empty spaces - what are we living for?

Abandoned places - I guess we know the score.

On and on!

Does anybody know what we are looking for?

\footnotetext{
${ }^{2}$ Was Chaucer guilty of plagiarism when leading French writers like Eustache Deschamps have gone on record as, not condemning him, but instead extolling him for making Le Roman de la Rose accessible to the English reading public and paying their homage in no uncertain terms by referring to him as 'great translator, noble Geoffrey Chaucer'?
} 


\section{Acknowledgement}

I am grateful to the CNPq for funding my research (Process no. 304557/ 2006-4)

\section{References}

DERRIDA, Jacques. Structure, sign and play in the discourse of the human sciences. In: Writing and Difference. Translated into English by Alan Bass. Chicago: University of Chicago Press, 1978 [1967].

RUSHDIE, Salman. In Good Faith. London: Penguin, 1990.

Recebido em janeiro de 2010. Aprovado em fevereiro de 2010. 